\title{
MAKNA BUDAYA DAN NILAI PENDIDIKAN KARAKTER DALAM SYAIR IKAN TERUBUK
}

\author{
Supriyadi ${ }^{1}$, Rian Hidayat ${ }^{2}$, Ridwan Tawaqal ${ }^{3}$ \\ Universitas Islam Riau, Pekanbaru, Indonesia ${ }^{1,2,3}$ \\ supriyadi@edu.uir.ac.id ${ }^{1}$,rianhidayat.mr@gmail.com ${ }^{2}$,ridwantawaqal@gmail.com ${ }^{3}$
}

\begin{abstract}
This study aimed to describe the characters' cultural meaning and educational values in the poem Ikan Terubuk. It explains that people's moral education results from the refinement of the values instilled since ancient times. Besides, it could also be useful for developing regional literature and enriching teaching materials for teachers of Indonesian language and literature and the learning of local culture, especially in the Riau. Thus, the poem Ikan Terubuk can be known and understood by the next generation so that local wisdom characteristics remain preserved and well maintained by the community. This type of research was qualitative with descriptive methods. The data collection technique used was the note-taking technique. The subject of this research was the poem Ikan Terubuk. This research aimed to focus on stylistic elements, cultural meanings, and educational values of character in the poem Ikan Terubuk. Data analysis through steps: data reduction, data presentation, and inference. The reliability of intra-rater and inter-rater obtained the validity of data. After clarifying the 10 data, it is reflected in the poetry of Ikan Terubuk, which is still developing contextually and has shifted functionally as a magical power in a ritual ceremony in Riau. The religious, nationalist, independent, cooperative, and integrity values showed moral education in this poem. The Islamic values became the dominant value in the poem Ikan Terubuk because it has relevance to the ethnic Malay majority Bengkalis as a devout Muslim.
\end{abstract}

Keywords: character education, poem Ikan Terubuk

\section{ABSTRAK}

Penelitian ini bertujuan Mendeskripsikan makna budaya yang dan nilai-nilai pendidikan karakter yang terdapat dalam syair Ikan Terubuk. Hal ini perlu dilakukan untuk menjelaskan bahwa pendidikan karakter yang kita kenal pada masa ini sebenarnya adalah hasil penyempurnaan dari nilai-nilai yang ditanamkan sejak zaman dahulu. Selain itu, juga dapat bermanfaat untuk pengembangan sastra daerah dan memperkaya bahan ajar bagi guru bahasa dan sastra Indonesia maupun pembelajaran budaya daerah yang ada khususnya di daerah Riau. Dengan demikian, syair Ikan Terubuk dapat dikenal dan dipahami keberadaannya oleh generasi berikutnya, sehingga ciri khas kearifan lokalnya tetap dilestarikan dan dijaga dengan baik oleh masyarakat. Jenis penelitian ini adalah kualitatif dengan metode deskriptif. Teknik pengumpulan data yang digunakan adalah teknik baca catat. Subjek penelitian ini adalah syair Ikan Terubuk. Objek penelitian ini difokuskan pada unsur stilistika, makna budaya, dan nilai pendidikan karakter dalam syair Ikan Terubuk. Analisis data melalui langkah-langkah: reduksi data, sajian data, dan penarikan kesimpulan. Keabsahan data diperoleh melalui validitas dan realibilitas berupa intrarater dan interrater. Hasil penelitian ini menunjukkan hal-hal sebagai berikut. Pertama, makna budaya dalam syair Ikan Terubuk ditandai dengan ditemukannya 10 data yang mencerminkan eksistensi budaya-budaya suku Melayu Riau khususnya Bengkalis melalui syair Ikan Terubuk yang hingga saat ini masih terus bertumbuh walaupun secara kontekstual syair Ikan Terubuk mengalami pergeseran fungsi karena mengaitkannya dengan kekuatan magis dalam sebuah ritual upacara di Riau. Kedua, nilai-nilai pendidikan karakter ditandai dengan: a) nilai pendidikan karakter religius, b) nilai pendidikan karakter nasionalis, c) nilai pendidikan karakter mandiri, d) nilai pendidikan karakter gotong royong, dan e) nilai pendidikan karakter integritas. Nilai pendidikan karakter religius (agama Islam)

Makna Budaya dan Nilai Pendidikan Karakter dalam Syair Ikan Terubuk 
menjadi nilai yang dominan terkandung di dalam syair Ikan Terubuk karena memiliki relevansi dengan suku Melayu Bengkalis yang sebagian besar beragama Islam yang taat.

\section{Kata Kunci: pendidikan karakter, syair Ikan Terubuk}

\section{PENDAHULUAN}

Nilai-nilai etika dan estetika dalam karya sastra sering terlupakan oleh gaya hidup instan dan serba praktis, berkembangnya teknologi dan semakin laju arus modernisasi seperti masuknya budaya asing dari luar telah banyak memberi perubahan dalam kehidupan masyarakat. Namun, perubahan yang terjadi banyak mengarah pada krisis moral. Jika melihat kenyataan yang ada dalam kehidupan sekarang, banyak kasus-kasus yang menunjukkan bahwa moral bangsa kita ini telah menurun dapat dilihat dari kasus-kasus seperti kejahatan, korupsi, kolusi, dan nepotisme bahkan sampai dengan terorisme. Selain itu, tawuran antarpelajar, sikap anak zaman sekarang yang cenderung tidak menghormati orang tua, dan banyak kasus lainnya yang seharusnya tidak dilakukan oleh siswa-siswa sekolah terjadi saat ini. Kasuskasus tersebut menunjukkan bahwa moral manusia telah menurun. Oleh karena itu, menjadi tanggung jawab semua pihak untuk memperbaiki penurunan moral dan akhlak tersebut dengan meningkatkan keimanan dan ketakwaan memalui pendidikan karakter. Sebagaimana substansi pendidikan adalah memanusiakan manusia, menempatkan kemanusiaan pada derajat tertinggi dengan memaksimalkan karya dan karsa (Erni \& Herwandi, 2018:18)

Pendidikan karakter adalah suatu sistem penanaman nilai-nilai karakter kepada warga sekolah yang meliputi komponen pengetahuan, kecerdasan atau kemauan, dan tindakan untuk melaksanakan nilai-nilai tersebut. Pendidikan karakter memiliki esensi dan makna yang sama dengan pendidikan moral dan pendidikan akhlak. Tujuannya adalah membentuk pribadi peserta didik, agar menjadi manusia yang baik, warga masyarakat dan warga negara yang baik.(T.Ramli, 2003:24)

Nilai-nilai pendidikan karakter bangsa tersebut secara tersirat terkandung di dalam karya sastra. Karya sastra mengandung unsur kebenaran serta keberanian untuk menampilkannya. Hal itu terdapat dalam berbagai tokoh dan watak, atau dalam bentuk utuh sebagai manusia maupun fabel. Pada akhirnya karya sastra memiliki kedudukan yang tidak bisa dianggap remeh dalam mempertahankan dan merekam suatu budaya. Sebaliknya karya sastra juga membentuk kebudayaan baru tanpa menghilangkan unsur budaya dan nilai-nilai pendidikan karakter yang positif.

Kuatnya arus asing telah melunturkan segenap nilai-nilai luhur bangsa Indonesia. Jika kita kaji lagi memang banyak peninggalan sejarah yang kita miliki sarat mengandung nilai-nilai yang luhur. Kurangnya minat untuk mengkaji peninggalan-peninggalan tersebut khusunya dalam dunia sastra menjadi alasan terbesar pudarnya nilai-nilai luhur dari karya sastra. Karya sastra adalah hasil olah pikir manusia terhadap sesuatu keadaan yang telah terjadi dan akan terjadi. Maka dari itu setiap karya sastra memiliki nilai-nilai yang sangat baik yang mampu mengajarkan kita untuk bertingkah laku dalam kehidupan sehari-hari. Selain itu karya-karya sastra juga memiliki unsur atau nilai-nilai keindahan yang mampu menggugah kita sebagai pembaca. Jika kita berbicara tentang peningglan karya sastra, khususnya sastra melayu klasik tentulah yang ada dalam pikiran kita hanyalah karya sastra yang telah sering kita dengar saja.

Syair merupakan salah satu dari beragam karya sastra yang mengandung nilainilai pendidikan karakter dan mempunyai aspek kebahasaan dengan keindahan bahasanya. Dalam dunia sastra, syair merupakan salah satu jenis puisi lama yang terkenal, karena sifat penciptaannya yang mempunyai kekuatan dalam menyampaikan suatu cerita. Sebagai salah satu jenis puisi, syair memperlihatkan keindahan bunyi bahasa melalui tatanan struktural berupa persajakan yang dapat menyatakan keindahan suatu karya. Di samping itu, kandungan nilai yang terdapat di dalam syair merupakan suatu hakikat atau manfaat penting dari keberadaan syair.

Makna Budaya dan Nilai Pendidikan Karakter dalam Syair Ikan Terubuk 
Selanjutnya, masyarakat yang mulai mengaraah menjadi masyarakat kapitalis sudah banyak meninggalkan seni daerah tradisional, misalnya bersyair. Tentu saja ini bukan hal yang aneh, karena di mana-mana yang namaya seni tradisional ketika berhadapan dengan kebudayaan kapitalis, baik secara estetis maupun politik kesenian secara berangsurangsur akan tergusur dan diasingkan. Perubahan seperti inilah yang pada dasarnya menjadikan seni tradisional dianaktirikan, sehingga penikmat karya sastra justru lebih mengutamakan kepentingan sastra yang kontemporer yang lebih bernuansa modernitas.

Dahulu orang bersastra untuk menghibur diri, beribadah, kegiatan sosial, mencari uang, merayakan sesuatu, dan lainlain. Kini mereka tidak begitu pasti untuk apa mereka berkesenian. Apalagi mereka telah dilanda arus globalisasi, akibat dari globalisasi, krisis identifikasi dan penghargaan terhadap kesenian tradisional tidak dapat terelakkan. Padahal, kandungan nilai suatu kesenian sastra lama merupakan unsur esensial secara keseluruhan dari semua karya seni. Pengungkapan nilai-nilai yang terdapat di dalamnya, bukan saja memberikan pengertian tentang latar belakang sosial budaya pengarangnya, melainkan juga dapat mengungkapkan ide-ide pengarang dalam menghadapi situasi-situasi yang mengelilinginya.

Dari kenyataan tersebut, diharapkan ada upaya menggali dan mengungkapkan serta mengukuhkan nilai-nilai sastra yang lama yang mempunyai potensi integratif dan masih relevan dengan tuntutan zaman. Perlu dipikirkan pengembangan nilai- nilai baru yang dapat berfungsi sebagai acuan guna mengembangkan sikap dan pola tingkap laku masyarakat yang sedang mengalami proses perubahan dan perkembangan. Selanjutnya sastra lama berperan sebagai motivator dan inspirasi. Kesadaran bahwa nilai- nilai kebudayaan daerah yang termuat dalam sastra lama yang masih relevan dengan kehidupan modern. Menurut Alber (2017:36) secara tidak langsung syair meruapakan basis dalam pendidikan karakter tidak hanya didasarkan pada nilai yang terkandung di dalamnya, tetapi juga sebagai strategi pelestarian kearifan lokal
Eksistensi syair Ikan Terubuk dan nilai-nilai pendidikan yang dikandungnya memiliki peranan yang sangat penting dalam kehidupan masyarakat Melayu Bengkalis pada abad ke-19, melalui rangkaian kata-kata syair ini dapat menyampaikan pesan-pesan pendidikan akhlak baik secara implisit maupun eksplisit. Namun demikian, memasuki era globalisasi dan era informasi saat ini peranan syair sebagai media penyampaian pesan-pesan pendidikan dalam kehidupan masyarakat khususnya masyarakat Melayu Bengkalis tersebut seakan telah hilang ditelan masa. Hal ini antara lain dapat dilihat dari fenomena yang terjadi bahwa intenstitas masyarakat dalam melantunkan syair Ikan Terubuk hanya dalam pentas seni dan hanya dalam acaraacara tertentu saja.

Bertolak dari uraian latar belakang di atas, pada gilirannya mendorong penulis untuk melakukan satu studi berjudul: "Makna Budaya dan Nilai Pendidikan Karakter dalam Syair Ikan Terubuk". Penulis juga berpendapat bahwa studi ini merupakan bidang garap yang cukup menarik sehingga layak untuk diteliti dan pada akhirnya bisa mengenal lebih banyak lagi karya sastra Melayu Klasik yang mulai memudar seiring perkembangan zaman dan agar kita bisa memahami unsur-unsur yang terkandung di dalamnya.

\section{A. KAJIAN PUSTAKA}

Syair ini populer di kalangan masyarakat Melayu Riau khususnya Bengkalis pada abad ke-19 yang lampau melalui media lisan, tanpa ada kejelasan siapa penciptanya, termasuk dalam model karya Anonim. Syair tersebut bukan hanya bersifat hiburan akan tetapi juga berisi contoh teladan dan nasihat orang tua, terutama kaum wanita dalam masyarakat Melayu Bengkalis pada masa itu, mereka sudah sangat terbiasa membaca Syair untuk mengisi waktu luangnya, terlebih pada malam hari menjelang tidur. Dengan demikian, pesan-pesan yang ingin disampaikan penulis melalui syair akan mudah dicerna dan dipahami. Dalam tradisi kehidupan orang-orang Melayu, ungkapanungkapan dalam bentuk pantun, syair, gurindam, peribahasa, seloka dsb, yang sering diselipkan dalam bahasa komunikasi sehari-

Makna Budaya dan Nilai Pendidikan Karakter dalam Syair Ikan Terubuk 
hari, yang di dalamnya mengandung petuah dan nasihat disebut juga dengan tunjuk ajar yang berkaitan dengan seluruh aspek kehidupan, mulai dari masalah keagamaan, sosial, kekeluargaan, akhlak, etika, moral hingga politik.

Syair ikan Terubuk merupakan sastra sarst makna dan bernilai tinggi yang mempunyai pengaruh signifikan terhadap kehidupan masyarakat Bengkalis.Ulul Azmi (2006:12) mengatakan bahwa karya sastra yang diciptakan pada abad ke-19 ini dibuat oleh seorang penyair yang memiliki pengetahuan luas mengenai kehidupan di dalam air, baik air asin maupun air tawar. Secara politik, rangkaian Syair Ikan Terubuk menggambarkan ambisi yang gagal dari penguasa lautan, yaitu ikan Terubuk untuk menguasai daerah pedalaman, putri PuyuPuyu. Jika ditarik pada konteks awal keberadaan syair tersebut, dapat diketahui bahwa Syair Ikan Terubuk menceritakan ambisi dari negeri pantai di wilayah Semenanjung Melayu, yang diwakili oleh Sultan Mahmud dari Melaka, untuk menaklukan negeri-negeri di daerah pedalaman, seperti Pagarruyung, Minangkabau dan negeri-negeri agraris lainnya.

Dalam perkembangannya, syair Ikan

Terubuk mengalami pergeseran nilai dan fungsi. Mulanya syair ini merupakan karya sastra sarat makna, kemudian beralih fungsi menjadi mantra pengundang yang mempunyai kekuatan magis. Perubahan dari sekedar karya sastra menjadi mantra berkekuatan magis menunjukkan adanya pergeseran makna dan fungsi dari Syair Ikan Terubuk. Masyarakat Bengkalis percaya bahwa pembacaan Syair Ikan Terubuk dapat mengundang ikan Terubuk yang "dipercaya" berasal dari selat Malaka agar datang berbondong-bondong ke wilayah perairan Bengkalis untuk bertelur, beranak pinak, hingga akhirnya dapat ditangkap oleh para nelayan setempat. Untuk menghadirkan kekuatan sakral sebagai mantra pengundang, Syair Ikan Terubuk selalu dibacakan dalam upacara mengundang ikan Terubuk. Upacara ini disebut semah laut. Pelaksanaan upacara semah laut dipandu oleh para Bathin (tetua adat) yang berasal dari kabupaten Bengkalis sendiri. Dalam upacara ini, para tetua adat berperan sebagai mediator untuk memanggil ikan-ikan Terubuk.

\section{Stilistika Kultural untuk Mengkaji Makna Budaya}

Stilistika merupakan sebuah ilmu yang mengkaji fungsi artistik penggunaan bahasa dalam berbagai konteks, termasuk karya sastra. Stilistika menjelaskanperihal ketepatan dan ketidaktepatan penggunaan berbagai unsur bahasa dalam sebuah teks. Stilistika berada dalam persinggungan studi linguistik, sastra , dan kultur (Nurgiyantoro, 2014:87). Stilistika sebagai salah satu kajian untuk menganalisis karya sastra. Stile adalah sebuah seleksi terhadap berbagai potensi bahasa yang ada pada sebuah bahasa, baik disadari maupun tidak oleh penuturnya. Seleksi itu digunakan tidak hanya untuk memeperindah bahasa saja, namun juga digunakan agar mampu mendukung muatan makna secara tepat. Muatan makna tersebut dalam beberapa hal juga kan dipengaruhi, atau bahkan ditentukan oleh nilai-nilai, norma, konvensi sosial atau ideologi masyarakat bahkan budaya pengguna bahasa tersebut (Nurgiyantoro, 2014:84). Hal ini juga menujukkan bahwa stile atau gaya bahasa sebagai unsur stilitika yang digunakan seorang penyair juga dipengaruhi oleh kultur dan budaya yang berkembang dimasyarakatnya. Tanpa keindahan bahasa, karya sastra menjadi hambar. Keindahan suatu karya sastra pasti dipengaruhi oleh kemampuan penulis mengolah kata, latar belakang kultur dan budaya penulisnya. Keindahan karya sastra juga memberikan bobot penilaian pada karya sastra itu. Seperti yang telah dijelaskan pada bagian sebelumnya pengkajian stilistika adalah terletak pada penggunaan bahasa dan gaya bahasa suatu sastra, dengan tujuan utamanya adalah meneliti efek estetika dan keindahan suatu bahasa. Keindahan juga merupakan bagian pengukur dan penentu dari sebuah sastra yang bernilai.

Stilistika kultural merupakan suatu pendekatan yang dipapakai dalam pengkajian gaya sebuah teks yang sarat muatan makna filosofis-kultural. Pemahaman gaya sebuah teks akan lebih tepat jika dilakukan dengan berangkat dan atau mempertimbangkan aspek 
kultur yang melatarbelakanginya. Teks sastra yang mengangkat aspek kultur masyarakat tampaknya lebih tepat jika didekati, dianalisis, atau dipahami dengan pendekatan stilistika kultural. Ada banyak karya sastra nusantara yang mengangkat latar belakang budaya melayu dengan aspek filosofis dan budayanya. Salah satunya adalah syair Melayu Ikan Terubuk yang mengisahkan kondisi sosial dan budaya masyarakat Melayu. Lewat pendekatan ini makna sebuah teks kesastraan dapat dipahami, digali, dan dijelaskan dengan baik. Pendekat ini juga penulis gunakan untuk pendekatan stilistika kultural untuk menejelaskan makna-makna budaya yang terdapat di dalam teks syair Melayu Ikan Terubuk.

\section{Nilai Pendidikan Karakter}

Nilai adalah sifat atau kualitas yang melekat pada suatu objek. Nilai suatu benda berarti kualitas baik atau buruknya benda. Pada hakikatnya nilai adalah suatu kenyataan yang tersembunyi di balik kenyataankenyataan yang ada. Menilai berarti menimbang suatu kegiatan manusia untuk menghubungkan dengan yang lain kemudian diambil keputusannya Kaelan (2004: 87). Selanjutnya Lubis (2008 : 18) mengatakan bahwa nilai merupakan esensi yang melekat pada sesuatu yang sangat berarti bagi kehidupan manusia. Keberadaan nilai akan menjadi tampak, seiring dengan kebutuhan yang diperlukan terhadap sesuatu tersebut. Nilai dapat dikatakan sebagai sesuatu yang berguna bagi kehidupan manusia. Dari beberapa pengertian tersebut dapat disimpukna bahwa pengertian nilai adalah pandangan atau anggapan terhadap sesuatu hal yang dilihat dari berbagai sudut pandang sehingga seseorang dapat menyebut sesuatu hal itu bagus atau baik atau buruk dan sebagainya.

Nilai-nilai yang dikembangkan dalam pendidikan karakter di Indonesia diidentifikasi dari empat sumber: (1) Agama, masyarakat Indonesia merupakan masyarakat beragama; (2) Pancasila, NKRI ditegakkan atas prinsipprinsip kehidupan kebangsaan dan kenegaraan yaitu Pancasila; (3) Budaya, nilai budaya dijadikan dasar karena tidak ada manusia yang hidup bermasyarakat yang tidak didasari nilai- nilai budaya; (4) Tujuan pendidikan nasional, berdasarkan Undang-undang Republik Indonesia Nomor 20 Tahun 2003 tentang Sistem Pendidikan Nasional.(Hasan dkk, 2010:8)

Berdasarkan keempat nilai tersebut, teridentifikasi 18 macam nilai dalam pendidikan karakter yaitu, jujur, toleransi, disiplin, kerja keras, kreatif, mandiri, demokratis, rasa ingin tahu, semangat kebangsaan, cinta tanah air, menghargai prestasi, bersahabat, cinta damai, gemar membaca, peduli lingkungan, peduli sosial, tanggung jawab. Dalam pengembangan pendidikan budaya dan karakter bangsa ada 18 nilai-nilai pendidikan karakter yang dibuat. (Kemendiknas, 2010:109).

Mulai tahun ajaran 2011, seluruh tingkat pendidikan di Indonesia harus menyisipkan pendidikan berkarakter tersebut dalam proses pendidikannya. Adapun 18 nilainilai dalam pendidikan karakter itu adalah religius, jujur, toleransi, disiplin, kerja keras, kreatif, mandiri, demokratis, rasa ingin tahu, semangat kebangsaan, cinta tanah air, menghargai prestasi, bersahabat/ komunikatif, cinta damai, gemar membaca, peduli lingkungan, peduli sosial dan tanggung jawab.

Sementara itu dalam panduan Penguatan Pendidikan Karakter (PPK) tahun 2016 yang dikeluarkan oleh Kementerian Pendidikan dan Kebudayaan ke-18 nilai pendidikan karakter sebelumnya di kelompokkan menjadi lima nilai utama yang meliputi; (1) religius; (2) nasionalis; (3) mandiri; (4) gotong royong; (5) integritas

\section{B. METODOLOGI PENELITIAN}

Penelitian tentang nilai pendidikan karakter dalam teks syair Ikan Terbuk adalah jenis penelitian kualitatif deskriptif. Sebagaimana dijelaskan oleh Moleong (2005:6) bahwa penelitian kualitatif adalah penelitian yang bermaksud untuk memahami fenomena tentang apa yang dialami oleh subjek penelitian misalnya perilaku, persepsi, motivasi, tindakan dll., secara holistik dan dengan cara deskripsi dalam bentuk kata-kata dan bahasa, pada suatu konteks khusus yang alamiah dan dengan memanfaatkan berbagai metode alamiah. Metode yang digunakan 
dalam penelitian ini adalah metode deskriptif, dimana data hasil temuan akan dideskripsikan, dianalisis diinterpretasi dan dismpulkan

Data dalam penelitian ini berupa kata pada setiap bait syair yang mengandung unsur makna budaya dan memuat nilai pendidikan karakter pada teks syair Ikan Terubuk. Penelitian ini dilakukan dengan mengambil dan menganalisis data sesuai dengan sumber data pada penelitian ini yaitu teks syair Ikan Terubuk. Naskah syair terdiri dari 285 bait yang dimuat dalam 75 halaman.

\section{HASIL DAN PEMBAHASAN}

\section{A. Makna Budaya pada Syair Ikan Terubuk}

Berdasarkan hasil penelitian ditemukan 10 data yang menunjukkan adanya unsur budaya suku Melayu di daerah Bengkalis, Riau yang tercermin dalam syair Ikan Terubuk. Berikut hasil penelitian makna budaya yang dikaji dengan stilistika kultural disajikan secara umum pada tabel. 6 di bawah ini.

Tabel 1. Makna Budaya dalam Syair Ikan Terubuk

\begin{tabular}{|c|c|}
\hline Data Makna Budaya & Jumlah \\
\hline $\begin{array}{l}\text { Memuji Allah sudahlah tentu } \\
\text { Salawatkan Nabi Alaihi Salatu }\end{array}$ & \multirow{10}{*}{10} \\
\hline Dengan kurnie Azza Wajalle & \\
\hline Sekali ini patik bertawakal & \\
\hline Patikpun asal hambe yang tue & \\
\hline Asalkan lepas dari kempunan & \\
\hline Pencak silat sangatlah pintar & \\
\hline Seperti budak terkene sawan & \\
\hline Sekarang bergelar Rajenye mude & \\
\hline Siang dan malam berlatih kuntau & \\
\hline Mandi berlimau tuan puteri & \\
\hline
\end{tabular}

\section{B. Nilai Pendidikan Karakter dalam Syair Ikan Terubuk}

Berdasarkan hasil penelitian ditemukan beberapa data yang menunjukkan adanya lima nilai pendidikan karakter dalam syair Ikan Terubuk. Berikut hasil penelitian nilai-nilai pendidikan karakter yang disajikan secara umum pada tabel di bawah ini.

Tabel 2. Nilai Pendidikan Karakter dalam Syair Ikan Terubuk

\begin{tabular}{|l|l|l|l|l|}
\hline $\mathbf{N}$ & NPK & Data & Juml & \% \\
\hline
\end{tabular}

\begin{tabular}{|c|c|c|c|c|}
\hline $\mathbf{0}$ & & & $\begin{array}{c}\text { ah } \\
\text { Data }\end{array}$ & \\
\hline 1 & Religius & $\begin{array}{l}\text { KR.1, KR.2, } \\
\text { KR.3, KR.4, } \\
\text { KR.5, KR.6, } \\
\text { KR.36, KR.49, } \\
\text { KR.54, KR.72, } \\
\text { KR.112, } \\
\text { KR.137, } \\
\text { KR.138, } \\
\text { KR.149, } \\
\text { KR.175, } \\
\text { KR.181, } \\
\text { KR.185, } \\
\text { KR.187, } \\
\text { KR.192, } \\
\text { KR.193, } \\
\text { KR.200, } \\
\text { KR.202, } \\
\text { KR.203, } \\
\text { KR.252, } \\
\text { KR.253, } \\
\text { KR.268, } \\
\text { KR.274 }\end{array}$ & $\begin{array}{c}27 \\
\text { data }\end{array}$ & $\begin{array}{l}38, \\
57\end{array}$ \\
\hline 2 & Nasional & $\begin{array}{l}\text { KN.48, KN.51, } \\
\text { KN.55, KN.59, } \\
\text { KN.61, KN.62, } \\
\text { KN.77, KN.113, } \\
\text { KN.171, } \\
\text { KN.172, } \\
\text { KN.179. }\end{array}$ & $\begin{array}{c}11 \\
\text { data }\end{array}$ & $\begin{array}{l}15, \\
71\end{array}$ \\
\hline 3 & Mandiri & $\begin{array}{l}\text { KM.6, KM.41, } \\
\text { KM.45, KM.59, } \\
\text { KM.64, KM.70, } \\
\text { KM.108, } \\
\text { KM.143, } \\
\text { KM.148, } \\
\text { KM.157, } \\
\text { KM.165, } \\
\text { KM.173, } \\
\text { KM.179, } \\
\text { KM.203, } \\
\text { KM.207, } \\
\text { KM.222, } \\
\text { KM.228, } \\
\text { KM.244, } \\
\text { KM.246. }\end{array}$ & $\begin{array}{c}19 \\
\text { data }\end{array}$ & $\begin{array}{l}27, \\
14\end{array}$ \\
\hline 4 & $\begin{array}{l}\text { Gotong } \\
\text { Royong }\end{array}$ & $\begin{array}{l}\text { KGR.39, } \\
\text { KGR.86, } \\
\text { KGR.104, } \\
\text { KGR.115, }\end{array}$ & $\begin{array}{c}8 \\
\text { data }\end{array}$ & $\begin{array}{l}11, \\
42\end{array}$ \\
\hline
\end{tabular}

Makna Budaya dan Nilai Pendidikan Karakter dalam Syair Ikan Terubuk 


\begin{tabular}{|c|c|l|c|c|}
\hline & & KGR.139, & & \\
& & & \\
& KGR.231, & & \\
KGR.239, & & \\
\hline 5 & Integritas & KI.3, KI.65, & 5 & 7, \\
& & KI.67, KI.77, \\
KI.224 & data & 14 \\
\hline
\end{tabular}

Keterangan:

NPK : Nilai Pendidikan Karakter

Pada syair Melayu Ikan Terubuk yang mengisahkan bagaimana seorang raja dengan sebutan ikan Terubuk jatuh cinta dengan seorang putri yaitu ikan Puyu-Puyu, pada syair Ikan Terubuk tersebut memiliki konflik bahwasanya rasa cinta ikan Terubuk tidak dapat tersampaikan karena adanya perbedaan di antara mereka yang berhubungan dengan asal diri. Perbedaan asal menyebabkan mereka tidak dapat bersatu. Pada syair Ikan Terubuk memiliki stile tertentu yang berbeda dengan syair lainnya. Aspek kultural yang dimiliki oleh suatu kelompok menjadi fundamental dalam memahami karya sastra termasuk syair Ikan Terubuk dan paada suatu keadaan tertentu kultur akan mempengaruhi berbagai aspek termasuk bahasanya.

Berdasarkan interpretasi melalui penggunaan bahasa Melayu Bengkalis Riau yang terdapat dalam syair Ikan Terubuk ditemukan 10 data yang menggambarkan budaya suku Melayu Riau sehingga melalui analisis stilistika kultural dapat ditemukan makna budaya yang terkandung di dalam syair Melayu Ikan Terubuk. Berikut beberapa data yang menunjukkan adanya makna budaya dalam syair Ikan Terubuk.

(3) Memuji Allah sudahlah tentu Salawatkan Nabi Alaihi Salatu Duduk mengarang dagang piatu Gundah gulane bukan suatu(MB.2)

Pada data (40) penggunaan bahasa dalam syair Ikan Terubuk tersebut menggambarkan budaya yang ada pada masyarakat suku Melayu khususnya di daerah Bengkalis, Riau. Diksi Allah dan Alaihi Salatu merupakan bahasa yang berasal dari bahasa Arab. Penggunaan bahasa Arab yang sangat sarat dalam syair Ikan Terubuk tersebut tentu beralasan. Masyarakat suku Melayu memiliki histori berdasarkan pendapat Van der Tuuk bahwa Melayu berarti penyebrangan yang memiliki pengertian bahwa orang-orang Melayu dahulu menyeberang atau menukar agamanya dari agama Hindu-Budha berganti menjadi agama Islam.

Agama Islam di daerah Melayu telah ada sejak abad 13 M. Kerajaan Siak adalah kerajaan Melayu Islam terbesar di Riau yang hingga saat ini dijadikan tempat koleksi benda-benda kerajaan. Kedatangan agama Islam memberikan perubahan yang dinamis bagi masyarakat suku Melayu termasuk adat istiadat, kesenian, bahasa, sastra, politik, dan aspek kehidupan lainnya. Sastra dan bahasa menjadi salah satu contoh kuatnya kehadiran agama Islam yang melekat dalam masyarakat Melayu khususnya Riau. Hal tersebut terbukti dengan penggunaan diksi yang mengandung unsur kepercayan terhadap agama Islam dan digunakan dalam syair untuk menyampaikan suatu maksud tertentu. Karim (2017) mengatakan bahwasanya ada keterkaitan yang sangat erat antara Melayu dan Islam yang merujuk pada istilah tidak Melayu kalau tidak Islam. Melayu sangat identik dengan agama Islam sebagai agama panutannya sehingga bagi orang-orang Melayu normanorma sosial orang Melayu harus berkiblat pada ajaran agama Islam dan sangat pantang untuk dilanggar.

Berdasarkan hal tersebut masyarakat Melayu pada umumnya identik dengan Islam yang menjadi pondasi dari sumber adat istiadatnya sehingga adat istiadat orang Melayu Riau bersendikan syarak dan syarak bersedikan Kitabullah. Kerangka pemikiran seperti itulah yang membentuk nilai-nilai ajaran Islam tidak dapat dilepaskan dari orang Melayu yang sudah menjadi budaya orang Melayu khususnya Bengkalis dan tercermin dalam syair Ikan Terubuk..

Berdasarkan hasil penelitian ditemukan kelima jenis pendidikan karakter dalam syair Ikan Terubuk sesuai yang dikemukakan oleh Kementerian Pendidikan dan Kebudayaan, yaitu: religius, nasionalis, mandiri, gotong royong, dan integritas sebanyak 70 data. Berikut pembahasan terkait dengan lima nilai pendidikan karakter yang ditemukan di dalam

Makna Budaya dan Nilai Pendidikan Karakter dalam Syair Ikan Terubuk 
syair Ikan Terubuk.

Itupun kodrat Tuhan Yang Ese

Kalbu di dalam rase binase

Hati berniat senantiase

Siang dan malam terase-rase (KR.4)

Pada data (47) penggunaan frase Tuhan Yang Ese menggambarkan nilai religius yang kuat di dalam syair Ikan Terubuk. Hal tersebut terbukti mulai pada bait pertama sebagai pembuka syair dan selanjutnya banyak sekali penggunaan diksi yang berkaitan dengan ajaran agama Islam mengingat suku Melayu didominasi oleh penganut agama Islam. Tuhan yang Ese menandakan bahwa keyakinan masyakarat Melayu Bengkalis atas keberadaan Tuhan yang satu dan mematuhi segala perintah serta ajarannya dalam menjalani kehidupan untuk mencapai surga-Nya. Percaya atas keesaan Tuhan juga berarti mempercayai kodrat yang telah ditakdirkan oleh Tuhan. Kepercayaan tersebutlah yang membentuk karakter masyarakat Melayu Bengkalis menjadi masyarakat yang religius dengan selalu mengaitkan segala ajaran agama Islam dalam kehidupan sehari-hari. Pola hidup masyarakat Melayu bengkalis yang seperti itulah yang menjadi khas suku Melayu sehingga terdapat ungkapan tidak Melayu kalau tidak Islam. Artinya, Melayu dan Islam menjadi satu kesatuan yang diyakini oleh sebagian besar masyarakat Melayu.

(51) Patikpun asal hambe yang tue Tiadelah takut membuang nyawe

Daripade tuanku akan kecewe Biarlah patik ditelan sawe (KN.51)

Pada data (51) ditemukan nilai nasionalis pada baris ketiga dan keempat yang mengindikasikan sikap rela berkorban seorang prajurit terhadap tuannya. Seseorang tersebut rela ditelan dengan ular sawo asalkan tuannya tidak kecewa. Bait pada syair Ikan Terubuk tersebut menggambarkan hakikat seorang prajurit di mana kewajibannya mengabdi kepada rajanya dan apabila dia berkorban demi rajanya maka dia merasa menjadi seorang prajurit yang beruntung dan telah menjalankan kewajibannya. Karakter yang nasionalis sudah ditanamkan sejak dahulu pada masyarakat suku Melayu mengingat zaman dahulu masih menggunakan sistem kerajaan.

\section{(56)}

Sekaliannye datang menghadap mude Meletakkan diri bertunde-tunde Untuk berperang melawan yang ade Mundurnye tidak majunye ade (KM.228)

Pada data (56) baris ketiga yaitu untuk berperang melawan yang ade mengandung nilai karakter mandiri yang diindikasikan dengan keberanian yang kuat untuk berperang tanpa mengandalkan orang lain. Di dalam syair Ikan Terubuk sangat banyak bait yang diulang untuk menekankan bahwasanya karakter suku Melayu merupakan manusia yang mandiri dalam melakukan sesuatu serta menyelesaikan masalah. Karakter mandiri menjadi salah satu karakter yang harus dimiliki oleh seorang manusia karena di dalam kehidupan kita tidak dapat selalu mengandalkan bantuan orang lain walaupun hakikatnya manusia merupakan mahluk sosial yang akan selalu membutuhkan orang lain.

\section{(57) Menyembah pule ikan umbut-umbut Tubuhnye besar badannye seput Jikalau datang mue menjemput Kitalah masuk ke dalam rumput (KGR.115)}

Pada data (57) terdapat dua bait yang mengandung nilai pendidikan karakter gotong royong. Nilai pendidikan karakter gotong royong menjadi salah satu nilai yang fundamental harus dimiliki oleh seseorang untuk menjalankan kehidupan yang harmonis antarsesama manusia. Bait ketiga dan keempat yaitu jikalau datang mue menjemput, kitalah masuk ke dalam rumput menandakan ada tindakan melakukan pekerjaan dengan bersama-sama yaitu masuk ke dalam rumput sebagai upaya penyelamatan diri. Pada syair Ikan Terubuk nilai pendidikan karakter gotong royong ditemukan dapat diinterpretasikan bahwasanya masyarakat suku Melayu gemar

Makna Budaya dan Nilai Pendidikan Karakter dalam Syair Ikan Terubuk 
bergotong royong dalam melakukan suatu kegiatan agar dapat tercapai hasil yang maksimal.

(60) Sudah diucap salawat yang akhir Dikarangkan pule suatu syair Hambe menyurat belumlah mahir Apetah lagi dawatnye cair (KI.13)

Berdasarkan data (60) mengandung nilai pendidikan karakter integritas pada bait ketiga yaitu hambe menyurat belumlah mahir. Nilai pendidikan karakter integritas ditandai dengan perilaku yang menjadikan dirinya menjadi seorang yang dapat dipercaya dalam perkataan dan tindakan. Dalam konteks syair di atas seseorang tersebut menyatakan bahwa tidak memiliki cukup kemampuan dalam menulis surat. Artinya, seseorang tersebut memiliki integritas yang tinggi dalam dirinya karena menyatakan dengan jujur atas kekurangmampuannya dalam menulis surat. Karakter seperti itu harus tetap ditanamkan pada diri seseorang dalam kehidupannya.

\section{SIMPULAN}

Berdasarkan hasil analisis data terkait dengan unsur-unsur stilistika, makna budaya, dan nilai-nilai pendidikan karakter dalam syair Ikan Terubuk dapat disimpulkan:

Pertama, makna budaya dalam syair Ikan Terubuk ditandai dengan ditemukannya 10 data yaitu: (1) memuji Allah sudahlah tentu Salawatkan Nabi Alaihi Salatu, (2) dengan kurnie Azza Wajalle, (3) sekali ini patik bertawakal, (4) patikpun asal hambe yang tue, (5) asalkan lepas dari kempunan, (6) kepade bertikam jangan dicapak, (7) seperti budak terkene sawan, (8) sekarang bergelar Rajenye mude, (9) siang dan malam berlatih kuntau, dan (10) mandi berlimau tuan puteri. Data tersebut mencerminkan eksistensi budayabudaya suku Melayu Riau khususnya Bengkalis melalui syair Ikan Terubuk yang hingga saat ini masih terus bertumbuh walaupun secara kontekstual syair Ikan Terubuk mengalami pergeseran fungsi karena mengaitkannya dengan kekuatan magis dalam sebuah ritual upacara di Riau.

$K e d u a$, nilai-nilai pendidikan karakter secara berurutan didominasi dengan: a) nilai pendidikan karakter religius, b) nilai pendidikan karakter mandiri), c) nilai pendidikan karakter nasionalis, d) nilai pendidikan karakter gotong royong, dan e) nilai pendidikan karakter integritas. Nilai pendidikan karakter religius (agama Islam) menjadi nilai yang dominan terkandung di dalam syair Ikan Terubuk karena memiliki relevansi dengan suku Melayu Bengkalis yang sebagian besar beragama Islam yang taat.

\section{REFERENSI}

Atmazaki. 2005. Ilmu Sastra: Teori dan Terapan. Padang: Citra Budaya Indonesia.

Atmazaki dan Hasanuddin. 1990. Pembacaan Karya Susastra sebagai Suatu Seni Pertunjukan. Padang: Angkasa Raya.

Alber. (2017). Tunjuk Ajar Melayu dalam Syair Karya Tenas Effendy Sebagai Basis Pendidikan Karakter. Junal GERAM, 6, 5-9.

Azmi, U. (2006). Syair IkanTerubuk. BKBPM. Burhan, N. (2014). Stilistika. Gadjah Mada University Press.

Erni, E., \& Herwandi, H. (2018). Pendidikan Nilai Karakter dalam Tradisi Lisan Nyanyi Panjang Bujang Si Undang pada Masyarakat Suku Petalangan Provinsi Riau. Geram, 6(1), 17-25. https://doi.org/10.25299/geram.2018.vol6 (1). 1258

Hasan. (2010). Bahan Pelatihan Penguatan Metodologi Pembelajaran Berdasarkan Nilai-Nilai Budaya Untuk Membentuk Daya Saing dan Karakter Bangsa. Kementerian Pendidikan Nasional Badan Penelitian dan Pengembanagan Pusat Kurikulum.

Kemdiknas. (2010). Pengembangan Pendidikan Budaya dan Karakter. Kemendiknas.

Moleong, L. J. (2005). Metode Penelitian Kualitatif. PT. Remaja Rosdakarya.

T.Ramli. (2003). Pendidikan Moral dalam Keluarga. grasindo.

Sugiyono. (2011). Metode penelitian pendidikan. Bandung: Alfabeta.

Syafaruddin. 2012. Pendidikan dan Pemberdayaan Masyarakat. Medan: Perdana Publishing 
Teeuw, A. 1984. Sastra dan Ilmu Sastra. Jakarta: Pustaka Jaya.

Turan, F., \& Ulutas, I. (2016). Using Storybooks as a Character Education Tools. Journal of Education and Practice, 7(15), 169-176.

Undang-Undang Republik Indonesia no 20 tahun 2003 Tentang Sistem Pendidikan Nasional (SISDIKNAS). 2007. Yogyakarta: Pustaka Pelajar. 